Boletín de la Sociedad Geológica Mexicana

VOLUMEN 67, NÚM. 1, 2015, P. 13-20

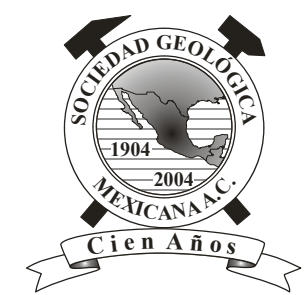

\title{
First reported occurrence of Palaeolama mirifica (Camelidae, Lamini) from the Late Pleistocene (Rancholabrean) of Puebla, central Mexico
}

\author{
Victor M. Bravo-Cuevas ${ }^{1, *}$, Eduardo Jiménez-Hidalgo ${ }^{2}$ \\ ${ }^{1}$ Museo de Paleontología, Área Académica de Biología, Universidad Autónoma del Estado de Hidalgo, Ciudad del Conocimiento, \\ Carretera Pachuca-Tulancingo, km 4.5, C. P. 42184, Pachuca, Hidalgo, México. \\ ${ }^{2}$ Laboratorio de Paleobiología, Instituto de Recursos, Campus Puerto Escondido, Universidad del Mar, Carretera Puerto Escondido- \\ Oaxaca km 2.5, C.P. 71980, Oaxaca, México. \\ *vmbc1@yahoo.com
}

\begin{abstract}
Palaeolama was a relatively rare camelid in North America during the Pleistocene. Here we report the first occurrence of $P$. $m i$ rifica in the Late Pleistocene of Puebla, central Mexico. This is the southernmost record of $P$. mirifica in North America, and fills in a geographic gap with a record of the species in Costa Rica. The fossil-bearing unit is composed of silt, fine sand, and scarce pebbles. This unit is partially correlative with the alluvial sequence of Axamilpa, Puebla, considered to be MIS $2-3$ in age. Isotopic data and Mesowear III values indicate that P. mirifica from Barranca Xocoa was an intermediate feeder.
\end{abstract}

Keywords: Camelidae, Palaeolama, Puebla, Late Pleistocene, central Mexico.

\section{Resumen}

Palaeolama fue un camélido poco común en Norteamérica durante el Pleistoceno. En este trabajo damos a conocer el primer

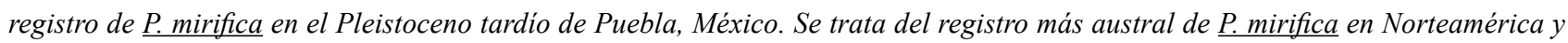
complementa su distribución geográfica con el registro de esta especie en Costa Rica. La unidad fosilifera consiste de limo, arena fina y escasa grava, la cual es parcialmente correlacionable con la secuencia de Axamilpa, Puebla, considerada de edad MIS 2-3. Datos isotópicos y de Mesodesgaste III indican que P. mirifica de Barranca Xocoa tuvo hábito alimentario mixto.

Palabras clave: Camelidae, Palaeolama, Puebla, Pleistoceno tardio, centro de México. 


\section{Introduction}

The family Camelidae includes the extant dromedary and bactrian camels of the Old World and llamas, alpacas, vicuñas, and guanacos of the New World (Wilson and Reeder, 2005). Camelids first appeared in North America during the middle Eocene and were present for about 40 million years (Honey et al., 1998; Prothero and Schoch, 2002). The lamines (Tribe Lamini), commonly referred to as llamas, radiated during the Miocene and Pliocene and became extinct in North America at the end of the Pleistocene, but have continued to survive in South America until the present (Carroll, 1988; Honey et al., 1998; Prothero and Schoch, 2002). Three genera of lamines, Camelops, Hemiauchenia and Palaeolama, inhabited North America during the Pleistocene (Kurtén and Anderson, 1980; Lange, 2002). Palaeolama seems to have been relatively uncommon in comparison to the other known North American lamines and is considered to be closely related to the living South American genus Lama (Webb, 1974; Honey et al., 1998).

The genus Palaeolama appears to have evolved in South America and is represented by multiple species: $P$. weddelli, P. major, P. aequatorialis and P. niedae (Webb, 1974). Currently the genus is considered to be monotypic in North America and all Pleistocene specimens are referred to P. mirifica (stout-legged llama). The chronological range of this species in North America goes from about 1.9 million to 10000 years ago (Kurtén and Anderson, 1980; Lange, 2002; Ruez, 2005). The oldest record of the genus in Mexico is a single occurrence referable to Palaeolama sp. from the Irvingtonian of Sonora, northern Mexico (Croxen et al., 2007). Previous to this record, in North America this species is known from South Carolina (Sanders, 2002), Coastal California, and several localities in the Gulf Coastal Plain (Texas and Florida) (Kurtén and Anderson, 1980), but the species has been reported as far south as Costa Rica (Pérez, 2013).

The purpose of this report is to describe the dental material of Palaeolama mirifica from the Late Pleistocene of Puebla, central Mexico, and comment on aspects of its geographic distribution and dietary behavior.

\section{Study Area}

The material studied here was recovered from the Barranca Xocoa (PUE-7) (1857'39.7” N, 9759'55.2” W, 2091 m.a.s.1.), located $21 \mathrm{~km}$ northeast of the Valsequillo Basin and approximately $24 \mathrm{~km}$ southeast of the city of Puebla de Zaragoza, capital of Puebla state (Figure 1). The fossil-bearing unit consists of silt, fine sand, and scarce pebbles, which are cemented with calcium carbonate, including travertine deposited from surface waters and consolidated to varying degrees. The fossil material reported here was recovered in the Valsequillo Basin by the staff of the Museo de Paleontología, Universidad Autónoma del Estado de Hidalgo, during the 2000 and 2001 field seasons. The sedimentary sequence at Barranca Xocoa is correlative

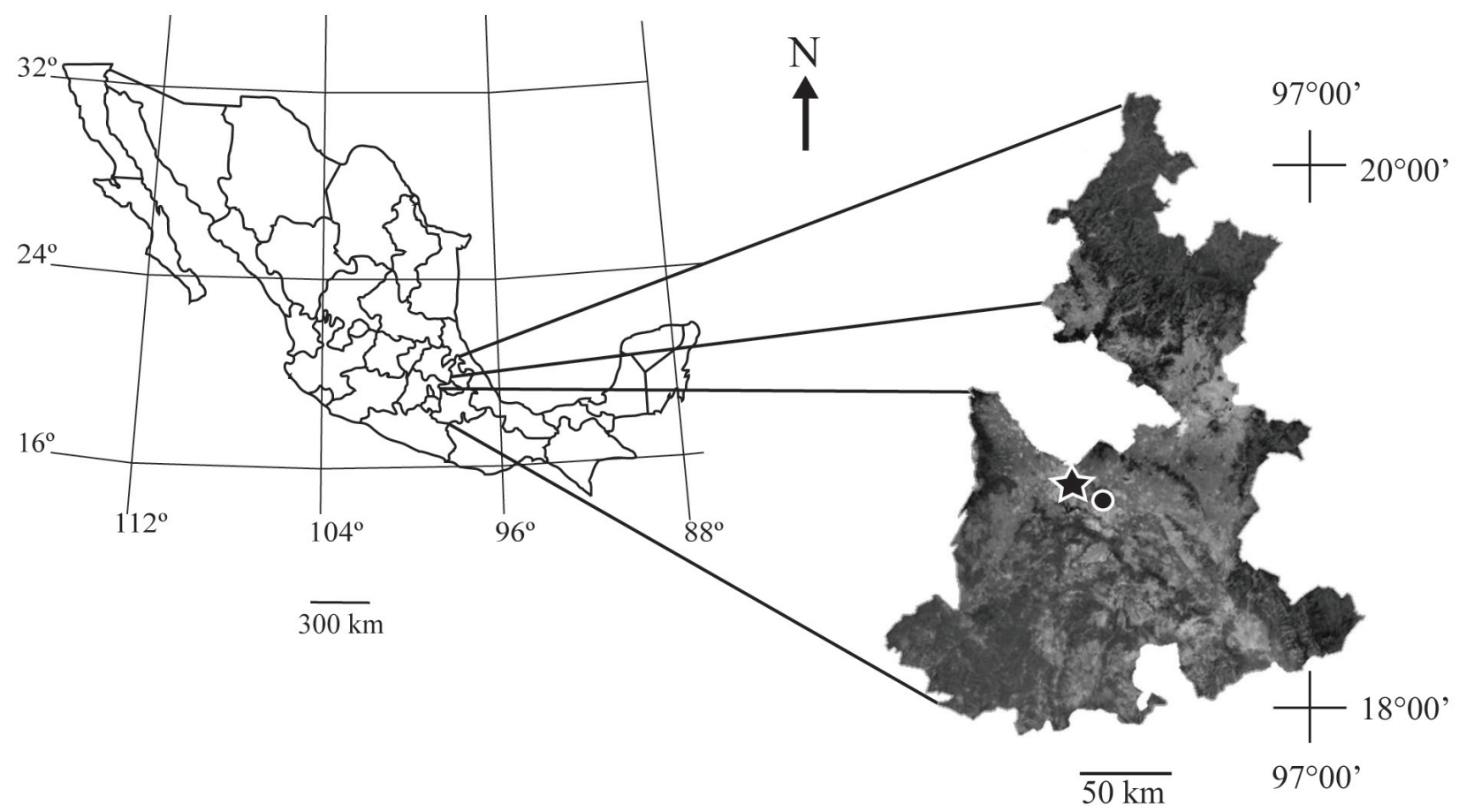

Figure 1. Index map of the study area, state of Puebla, central Mexico. The capital of the state, Puebla de Zaragoza city, (star) and the Late Pleistocene locality Barranca Xocoa (PUE-7) (circle) are depicted. 
to some extent with the Quaternary alluvial sequence of Axamilpa, southern Puebla, which is considered to be MIS (Marine Isotope Stage) 3-2 in age (59000 - 27000 years) (Tovar et al., 2014).

Associated fauna includes fossil remains of turtles (Testudine indet.), horses (Equus sp.), mammoths (Mammuthus sp.), antilocaprids (cf. Stockoceros sp.), and bisons (Bison sp.). The presence of a 5 th/6th thoracic vertebra of Bison is indicative of the Rancholabrean North American Land Mammal Age (NALMA) (Bell et al., 2004).

\section{Materials and Methods}

The sample includes two isolated teeth that are housed at the Sección de Macrovertebrados, in the Museo de Paleontología, Universidad Autónoma del Estado de Hidalgo, México (UAHMP) with the numbers UAHMP-552 and UAHMP-553. A comparison of the material from Puebla with the dental morphology of the genera Camelops and Hemiauchenia is provided. The Mexican specimens were compared with teeth of Palaeolama mirifica housed at the vertebrate paleontology collections of Los Angeles County Museum (LACM), Los Angeles, California; the Fossil Mammal Collection of the American Museum of Natural History (F:AM), New York; Texas Memorial Museum, Austin, Texas (TMM); and the Florida Museum of Natural History (UF), Gainesville, Florida, U. S. A.

The dental nomenclature follows the scheme designed by Bärmann and Rössner (2011). The crown height, anteroposterior length, and transverse width of each tooth were measured at the occlusal surface using a digital caliper. All measurements are in millimeters.

To establish the geographic distribution of Palaeolama mirifica in North America during the Pleistocene, its occurrences were compiled from the FAUNMAP database of NeoMap (Graham and Lundelius, 2010) and the Paleobiology Database (PaleoDB, 2014).

The dietary behavior of Palaeolama mirifica from the Pleistocene of Puebla was characterized through carbon isotope analysis in tooth enamel, and by applying the new method of tooth mesowear proposed by Solounias et al. (2014).

A bulk sample of enamel was obtained for both teeth. The enamel flake extraction and its chemical treatment were performed following the protocols of MacFadden and Cerling (1996) and Koch et al. (1997). The samples were analyzed using a Finnigan MAT 253 mass spectrometer, attached to a Finnigan Gas Bench II on-line gas preparation system at the Laboratorio Universitario de Geoquímica Isotópica (LUGIS), Universidad Nacional Autónoma de México. Isotopic values are expressed in standard $\delta$-notation and are reported relative to the V-PDB standard (Vienna Pee Dee Belemnite) (after Craig, 1957).

In order to differentiate between a browsing and a grazing diet, the new method of tooth mesowear known as Mesowear III was applied (Solounias et al., 2014). We evaluated the mesial and distal surfaces of enamel band 2 in the paracone and metacone of the third upper molar. The mesowear scores of Solounias et al. (2014) were used to characterize a particular dietary behavior. A mesowear score of 1 indicates a typical browser (planar surfaces and junction point well differentiated), and a mesowear score of 4 indicates a typical grazer (rounded surfaces and junction point undistinguishable); mesowear scores of 2 and 3 indicate intermediate feeders (Solounias et al., 2014, fig. 2, p. 113).

\subsection{Abbreviations}

APL/apl, upper/lower anteroposterior tooth length; $\mathrm{CH} /$ ch, upper/lower crown height; L, left; M/m, upper/lower molar; R, right; TW/tw, upper/lower transverse tooth width.

\section{Systematic paleontology}

Order Artiodactyla Owen, 1848

Family Camelidae Gray, 1821

Tribe Lamini Webb, 1965

Genus Palaeolama Gervais, 1869

Palaeolama mirifica Simpson, 1929

Figures 2-3, Tables 1-2

\subsection{Description}

\subsubsection{Upper tooth}

Specimen UAHMP- 552 is a third upper molar. It is brachyodont, lacks a layer of cementum, and the enamel is crenulated; the styles and ribs are well developed; the protocone is $\mathrm{V}$-shaped with a blunt tip, whereas the metaconule is U-shaped; the protocone is wider than the metaconule; and the anterior and posterior fossettes are simple and sinuous in outline (Figure 2).

\subsubsection{Lower tooth}

Specimen UAHMP-553 is a third lower molar. The tooth is also brachyodont, lacks cementum, and has crenulated enamel. The fossettes are simple, elongated anteroposteriorly, and constricted in the middle. The anterior stylid and metastylid are somewhat developed. The protoconid is broken; the hypoconid is U-shaped; the hypoconulid is rounded, well developed, and is separated from the second crescent by a pronounced constriction. The roots are deep and well developed (Figure 3).

\subsection{Referred material}

Locality Barranca Xocoa (PUE-7): UAHMP-552, RM3; UAHMP-553, Lm3. 
A

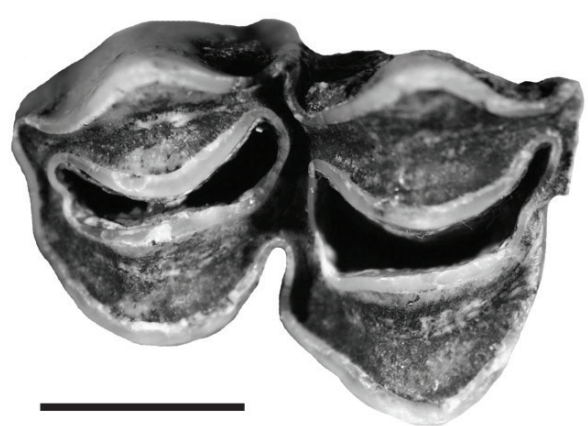

B

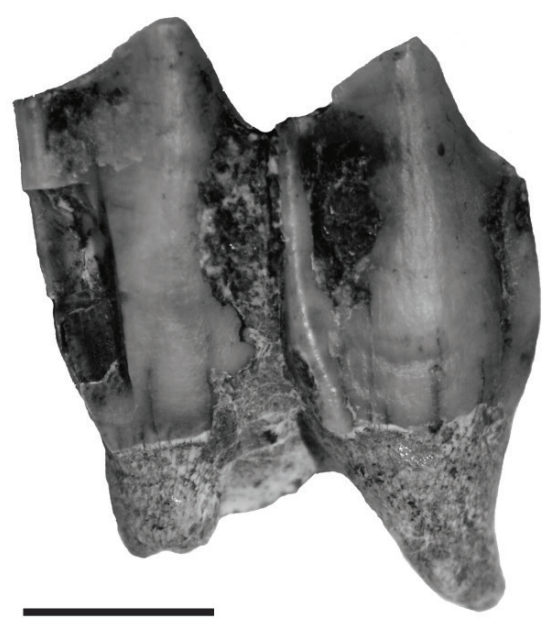

Figure 2. Upper last molar of Palaeolama mirifica from the Late Pleistocene (Rancholabrean) of Puebla, central Mexico. UAHMP-552 (RM3): A, occlusal view (right anterior, down lingual) and $\mathrm{B}$, lateral view (right posterior). Scale bars: $1 \mathrm{~cm}$.

\subsection{Age and ocurrence}

Earliest occurrence of Palaeolama mirifica is from the latest Blancan of Florida (Bell et al., 2004; Ruez, 2005). Although rare in North American Pleistocene faunas, the species distribution was widespread during the Rancholabrean, including localities in California, Texas, Florida (Kurtén and Anderson, 1980), South Carolina (Sanders, 2002) as well as the new locality, reported here, in Puebla, central Mexico, and Costa Rica (Pérez, 2013).

\section{Discussion}

\subsection{Taxonomic assessment}

The specimens from Puebla show several diagnostic features of the teeth characteristic of Palaeolama, including: (1) low crowned cheek teeth with an angular appearance; (2) upper molars with strong external styles and ribs; (3) teeth
A
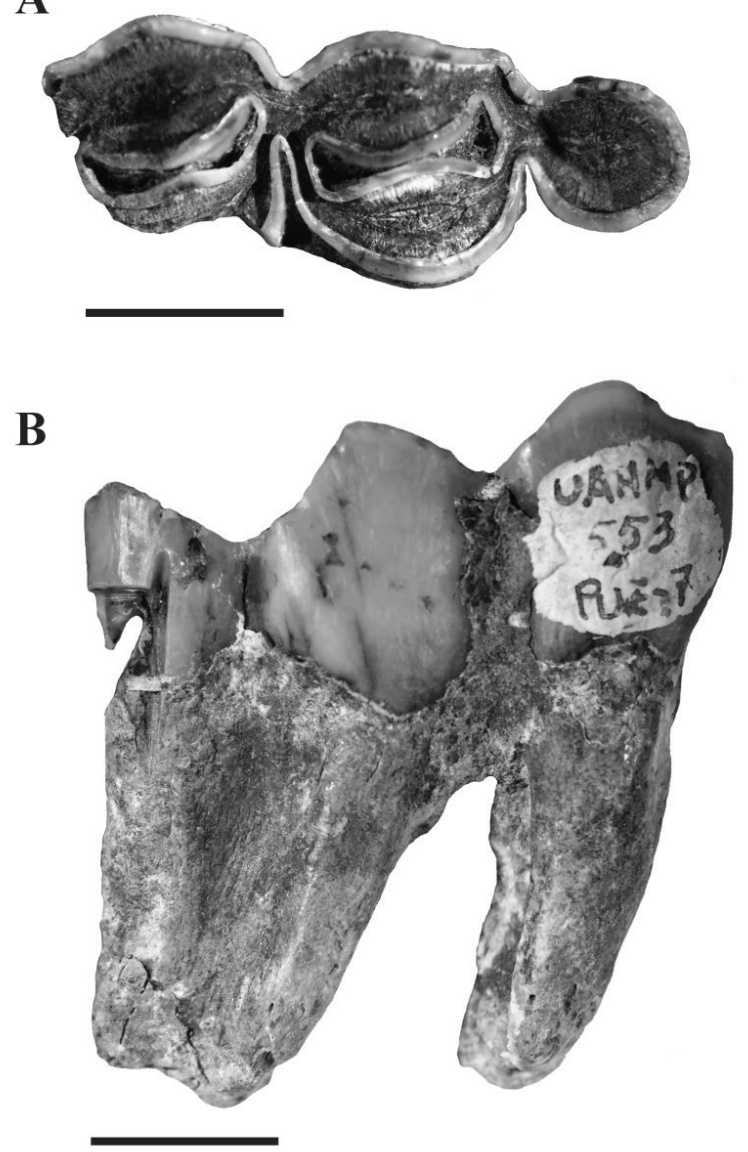

Figure 3. Lower last molar of Palaeolama mirifica from the Late Pleistocene (Rancholabrean) of Puebla, central Mexico. UAHMP-553 (Lm3): A, occlusal view (left anterior, down lingual) and B, lateral view (right anterior). Scale bars: $1 \mathrm{~cm}$.

lacking cementum; and (4) crenulated enamel (Kurtén and Anderson, 1980; Honey et al., 1998). The genus Camelops is distinguished from the study sample by having cheek teeth very hypsodont and upper molars with reduced external styles (Kurtén and Anderson, 1980; Honey et al., 1998). In addition, the genus Hemiauchenia differs from the Puebla material in having cheek teeth covered by cementum with a small degree of crenulation (Webb, 1974).

The dental morphology of UAHMP-552 (RM3) corresponds to that of M3s of Palaeolama mirifica in possessing acute and not rounded crescents, protocone that is wider than metaconule, and simple fossettes that are sinuous in outline. The specimens LACM 28821 (LM3 from Emory Borrow Pit, California, Late Pleistocene), F:AM 28821 (LM3 from Seminole Field, Florida, Late Pleistocene), and TMM 30967-2575 (RM3 from Ingleside, Texas, Late Pleistocene) all have well developed roots; a similar condition is observed in the isolated upper third molar described here. The mesostyle crown height of UAHMP-552 (RM3) is about $16 \mathrm{~mm}$, which is close to that of the specimens F:AM 23485 (LM3) from Seminole Field, 
Florida (Late Pleistocene) and TMM 30967-2575 (RM3) from Ingleside, Texas (Late Pleistocene), but it is slightly different from specimens LACM 2682 (LM3) from Emory Borrow Pit, California (Late Pleistocene) and F:AM 23109 (RM3) from Seminole Field, Florida (Late Pleistocene). The size of the teeth of the material from Puebla is similar to that of specimens from the Late Pleistocene of Coastal California and the Gulf Coastal Plain, considering that average differences in the anteroposterior length and transverse width are $2 \mathrm{~mm}$ and $4 \mathrm{~mm}$, respectively (Table 1).

The dental morphology of UAHMP-553 (Lm3) is similar to that of Palaeolama mirifica represented by TMM 30967-944 (Rm3) and TMM 30967-2567 (Lm3) from Ingleside, Texas (Late Pleistocene), as well as the $\mathrm{m} 3$ of F:AM 22717 (associated maxilla with RM1-RM3 and LP4-M3 and a mandible fragment with Rm3) from Seminole Field, Florida (Late Pleistocene) and the Lm3 of UF 1093 (left mandible with $\mathrm{p} 3-\mathrm{m} 3$ ) from Arredondo 1B, Florida (Late Pleistocene). These specimens share the presence of a somewhat developed mesostylid, simple fossettids that are elongated anteroposteriorly, and a well-developed hypoconulid, separated by the second crescent by a marked constriction. The size of the tooth from Puebla is similar to that of the specimens from the Gulf Coastal Plain of Florida and Texas (Table 2).

The comparisons show that the size and morphology of the teeth from the Late Pleistocene of Puebla, are closely similar to the M3s $/ \mathrm{m} 3 \mathrm{~s}$ of Palaeolama mirifica. Hence, the

Table 1. Selected measurements (in millimeters) of UAHMP-552 from Puebla (central Mexico) and upper third molars of Palaeolama mirifica from the Late Pleistocene (Rancholabrean) of the California Coast and Gulf Coastal Plain (Florida and Texas), United States. Abbreviations: $\mathrm{CH}$, crown height; APL, anteroposterior length; TW, transverse width. Vertebrate paleontology collections: UAHMP, Universidad Autónoma del Estado de Hidalgo, Museo de Paleontología; LACM, Los Angeles County Museum, Los Angeles, California; F:AM, Fossil Mammal Collection of the American Museum of Natural History; TMM, Texas Memorial Museum, Austin, Texas.

\begin{tabular}{|c|c|c|c|c|}
\hline Specimen & Position & $\mathrm{CH}$ & APL & TW \\
\hline \multicolumn{5}{|c|}{ Barranca Xocoa, Puebla, central Mexico } \\
\hline UAHMP-552 & RM3 & 16.91 & 26.49 & 18.85 \\
\hline \multicolumn{5}{|c|}{ Emory Borrow Pit, California } \\
\hline LACM 26821 & LM3 & 21.27 & 28.99 & 21.45 \\
\hline \multicolumn{5}{|c|}{ Seminole Field, Florida } \\
\hline F:AM 23109 & RM3 & 12.58 & 27.06 & 28.2 \\
\hline F:AM 22717 & RM3 & --- & 27.58 & 19.32 \\
\hline F:AM 23485 & LM3 & 19.07 & 24.09 & 16.3 \\
\hline \multicolumn{5}{|l|}{ Ingleside, Texas } \\
\hline TMM 30967-1589 & RM3 & --- & 25.75 & 18.77 \\
\hline TMM 30967-92 & LM3 & --- & 24.15 & 15.27 \\
\hline TMM 30967-372 & RM3 & --- & 24.57 & 14.51 \\
\hline TMM 30967-2575 & RM3 & 19.53 & 27.37 & 18.01 \\
\hline
\end{tabular}

Table 2. Selected measurements (in millimeters) of UAHMP-553 from Puebla (central Mexico) and lower third molars of Palaeolama mirifica from the Pleistocene (Rancholabrean) of the Gulf Coastal Plain (Florida and Texas), United States. Abbreviations: ch, crown height; apl, anteroposterior length; OR, observed range; tw, transverse width; $x$, mean. Vertebrate paleontology collections: UAHMP, Museo de Paleontología, Universidad Autónoma del Estado de Hidalgo; F:AM, Fossil Mammal Collection of the American Museum of Natural History; UF, Florida Museum of Natural History, Gainesville, Florida; TMM, Texas Memorial Museum, Austin, Texas.

\begin{tabular}{|c|c|c|c|c|}
\hline Specimen & Position & $\mathrm{ch}$ & apl & tw \\
\hline \multicolumn{5}{|c|}{ Barranca Xocoa, Puebla, central Mexico } \\
\hline UAHMP-553 & Lm3 & 14.38 & 32.85 & 12.8 \\
\hline \multicolumn{5}{|c|}{ Seminole Field, Florida } \\
\hline F:AM 22717 & $\mathrm{Rm} 3$ & -- & 31.66 & 12.28 \\
\hline \multicolumn{5}{|c|}{ Arredondo 1B, Florida } \\
\hline UF1093 & Lm3 & & 34.78 & 13.52 \\
\hline \multicolumn{5}{|l|}{ Ingleside, Texas } \\
\hline TMM 30967- 314 & Lm3 & 12.03 & 32.23 & 14.25 \\
\hline TMM 30967- 1090 & $\operatorname{Lm} 3$ & 19.32 & 30.58 & 12.06 \\
\hline TMM 30967- 289 & $\mathrm{Rm} 3$ & 20.69 & 32.63 & 13.32 \\
\hline TMM 30967- 1696 & $\mathrm{Rm} 3$ & 12.47 & 29.58 & 14.79 \\
\hline TMM 30967- 1500 & Lm3 & --- & 31.07 & 15.1 \\
\hline TMM 30967- 1676 & Lm3 & --- & 28.67 & 13.82 \\
\hline TMM 30967- 445 & $\mathrm{Rm} 3$ & --- & 31.98 & 14.84 \\
\hline TMM 30967- 1274 & $\operatorname{Lm} 3$ & --- & 29.72 & 14.38 \\
\hline TMM 30967-2567 & $\operatorname{Lm} 3$ & 18.96 & 31.46 & 12.84 \\
\hline \multirow[t]{3}{*}{ TMM 30967-944 } & $\mathrm{Rm} 3$ & 14.17 & 31.75 & 13.98 \\
\hline & & & $x=30.96$ & $x=13.93$ \\
\hline & & & OR $28.67-32.63$ & OR $12.06-15.10$ \\
\hline
\end{tabular}

dental sample considered here has been formally referred to that species.

\subsection{Geographic distribution and biochronology}

The oldest records of Palaeolama mirifica are from the latest Blancan of Florida (Ruez, 2005). There are records in California and Florida (Figure 4), and in the Rancholabrean the records of this llama are from South Carolina, Texas, and Florida (Figure 4); in addition there is a record from Costa Rica (Pérez, 2013). Thus, the presence of this llama in Puebla extends its former Pleistocene geographic distribution southwardly, from southern United States to central Mexico, representing the most southern occurrence within North America (Figure 4) and fills the geographic gap with the Costa Rican record.

In Mexico, there is a record referable to Palaeolama sp. from the Early Pleistocene (Irvingtonian) of Sonora, northern Mexico (Croxen et al., 2007). The material described here constitutes the youngest record of the genus in this country, extending its biochronological range from the Irvingtonian to Rancholabrean.

According to the major biogeographic corridors of Ceballos et al. (2010), the records of Palaeolama from the Irvingtonian of Sonora (northern Mexico) (Croxen 
et al., 2007), and those of South Carolina, Texas, and Florida, as well as that described in the present study from the Rancholabrean of Puebla (central Mexico), suggest that this llama used the tropical corridors of the SonoraCentral America Pacific lowlands (western route) and the Tamaulipas-Central America Gulf lowlands (eastern route) during the Pleistocene.

\subsection{Dietary behavior}

\subsubsection{Carbon isotope analysis}

A diet consisting primarily of $\mathrm{C} 3$ plants (= browsers and high latitude grazers) is indicated by $\delta^{13} \mathrm{C}$ values of less than $-10 \%$, whereas a diet consisting primarily of $\mathrm{C} 4$ plants (= tropical and sub-tropical grazers) is indicated by $\delta^{13} \mathrm{C}$ values greater than $-1 \%$; intermediate values of $\delta^{13} \mathrm{C}$ from $-1 \%$ to $-10 \%$, indicate a diet consisting of both $\mathrm{C} 3 / \mathrm{C} 4$ plants (= mixed feeders) (Koch et al., 1992; Quade et al., 1992; Cerling et al., 1997). The relative percentage of C4 plants incorporated into the diet was estimated using the mass balance equation of Koch et al. (2004).

The minimum and maximum $\delta^{13} \mathrm{C}$ isotope values of Palaeolama mirifica from Puebla are $-2.08 \%$ and $-1.83 \%$ o respectively, with a mean value of $-1.96 \%$. The estimated percentage of $\mathrm{C} 4$ plants intake is of about $70 \%$. The data are suggestive of a mixed diet consisting of both $\mathrm{C} 3 / \mathrm{C} 4$ plants, with an emphasis on $\mathrm{C} 4$ plants.

Palaeolama mirifica has been considered as a browser that dwelled in forested environments (Kurtén and Anderson, 1980; Kohn et al., 2005; Semprebon and Rivals,

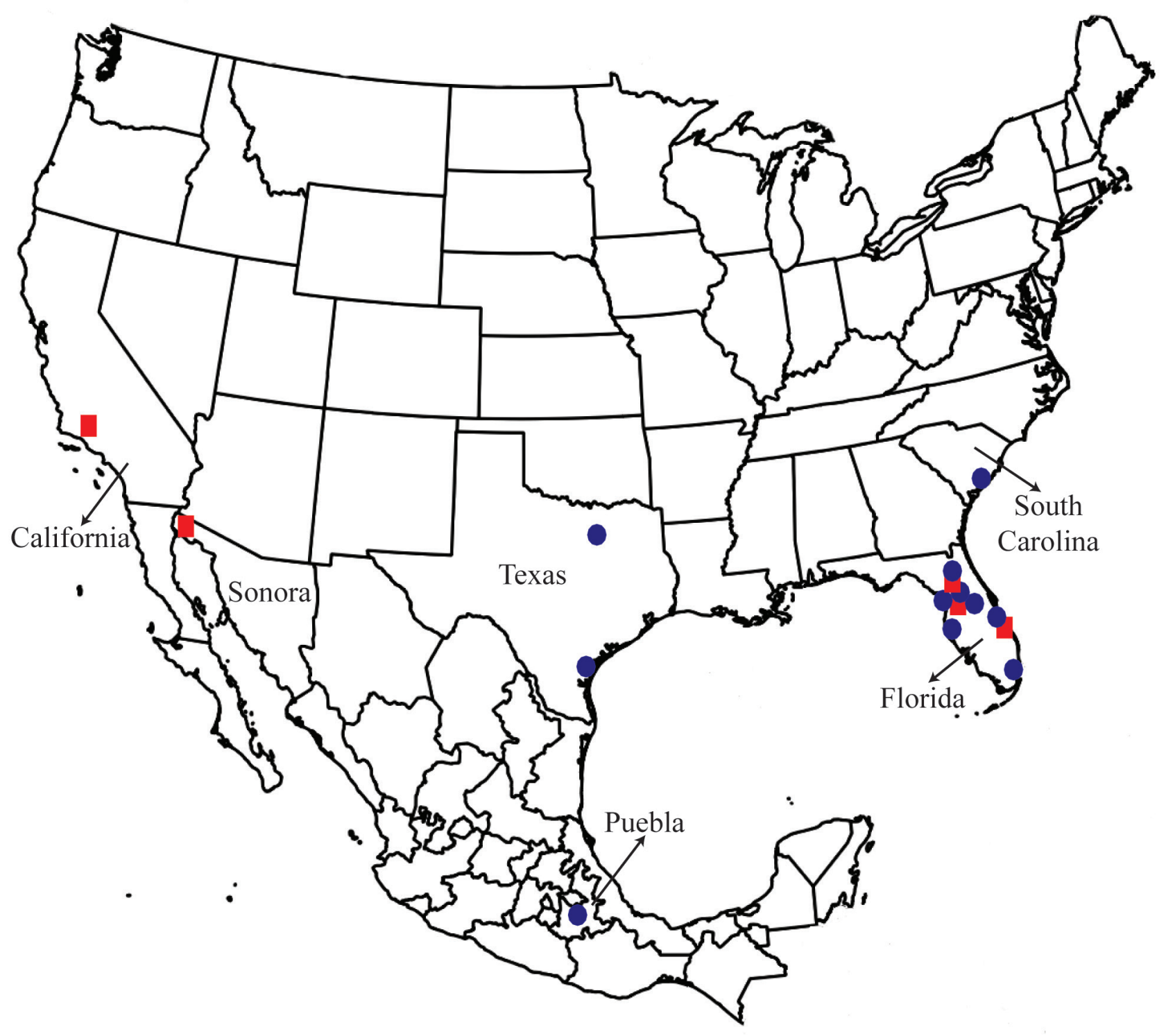

Figure 4. Geographic distribution of Palaeolama mirifica in North America during the Pleistocene. Red squares are the Irvingtonian records of California and Florida in the United States of America, as well as that of Golfo de Santa Clara, Sonora, México. Purple dots are the Rancholabrean records in Texas, Florida and South Carolina in USA and the new record from Puebla, central Mexico. 
2010). The $\delta^{13} \mathrm{C}$ isotope values of $P$. mirifica from Leisey Shell Pit, Florida (Irvingtonian) range from $-12 \%$ to $-15 \%$, indicating a diet consisting primarily of $\mathrm{C} 3$ plants (DeSantis et al., 2009). The carbon isotope values for the sample studied here are more positive (with a mean difference of $-11 \%$ ) and indicate a mixed dietary behavior with increased consumption of $\mathrm{C} 4$ plants. This difference may be explained as flexibility in dietary behavior of this llama, which in turn suggests an adaptable dietary regime related to local environmental conditions, but there is clearly a need to broaden the carbon isotope data of Mexican Palaeolama upon which this issue could be suitably discernible.

\subsubsection{Dental wear pattern (Mesowear III)}

The second enamel bands on the paracone and metacone of UAHMP-552 are planar, the mid-point junction among these enamel bands ( $\mathrm{j}$-point) is distinguishable and shows a rounded surface; furthermore, both enamel bands have gouges on the buccal side. This description corresponds to a Mesowear III score of 2 (Solounias et al., 2014). According to Solounias et al. (2014) mesowear scores 2 and 3 are indicative of intermediate feeders. Particularly, the mesowear score of the tooth belonging to Palaeolama mirifica from the Pleistocene of Puebla is in the lower limit of Mesowear III scores for extant mixed feeders (Solounias et al., 2014, fig. 3, p. 115).

A sample of Palaeolama mirifica from the Rancholabrean of California was interpreted as an intermediate feeder by SEM (scanning electron microscopy) microwear analysis (Dompierre, 1995). Hence, the observed dental mesowear pattern of the studied sample gives additional information of the potential capability of $P$. mirifica for exploiting both browsing (succulent) and grazing (abrasive) resources.

\section{Conclusions}

The comparative study of a dental sample from the Late Pleistocene (Rancholabrean) of Puebla, central Mexico, recognizes the presence of the stout-legged llama Palaeolama mirifica. This material represents the first record in Mexico formally described and assigned to that species.

The record of Palaeolama mirifica from Puebla constitutes (so far) the southernmost occurrence of this llama within North America, and fills the geographic gap of the record of this species in Costa Rica, whereas in Mexico is the youngest occurrence of the genus.

The carbon isotope analysis of tooth enamel and the evaluation of dental mesowear pattern (Mesowear III) of the material studied here showed that the sample of Palaeolama mirifica from the Late Pleistocene of Puebla, central Mexico, ate both C3 and C4 (succulent/abrasive) plant resources. Hence, this sample indicates it was an intermediate feeder and was capable of exploiting different kinds of plant resources.

\section{Acknowledgements}

We thank Grant D. Zazula (Government of Yukon Paleontology Program) and Hugh Gregory McDonald (National Park Service) for their comments and suggestions on the manuscript. Thanks to Pedro Morales Puente and Edith Cienfuegos Alvarado (Laboratorio de Geoquímica Isotópica, Universidad Nacional Autónoma de México) for their support with the isotopic analysis. VMBC thanks Samuel A. McLeod and Vanessa R. Rhue, and Chris Sagebiel for their kind support during his visits to the Vertebrate Paleontology collections at the Natural History Museum of Los Angeles County and at the Texas Memorial Museum respectively. EJH thanks Jin Meng for the approval to visit the Fossil Mammal Collection of the American Museum of Natural History and Judy Galkin for her kind help during that visit. Thanks to E. Lundelius for sharing information on Pleistocene mammalian faunas of the Texas Gulf Coastal Plain. This study is part of the project CONACyT-Ciencia Básica (CB-2009-130712): "El registro de ungulados terrestres en el Pleistoceno de Hidalgo, Puebla y Tlaxcala, centro de México: Interpretación de hábitos alimentarios y caracterización de paleocomunidades terrestres".

\section{References}

Bärmann, E.V., Rössner, G.E., 2011, Dental nomenclature in Ruminantia: Towards a standard terminological framework: Mammalian Biology, $76,762-768$.

Bell, C.J., Lundelius, E.L. Jr., Barnosky, A.D., Graham, R.W., Lindsay, E.H., Ruez, D.R. Jr., Semken, H.A. Jr., Webb, S.D., Zakrzewski, R.J., 2004, The Blancan, Irvingtonian, and Rancholabrean mammal ages, in Woodburne, M.O. (ed.), Late Cretaceous and Cenozoic mammals of North America: New York, Columbia University Press, 232-314.

Carroll, R.L., 1988, Vertebrate paleontology and evolution: New York, W. H. Freeman and Company, 698 p.

Ceballos, G., Arroyo-Cabrales, J., Ponce, E., 2010, Effects of Pleistocene environmental changes on the distribution and community structure of the mammalian fauna of Mexico: Quaternary Research, 73, 464-473.

Cerling, T.E., Harris, J.M., MacFadden, B.J., Leakey, M.G., Quade, J., Eisenmann, V., Ehlinger, J.R., 1997, Global vegetation change through the Miocene/Pliocene boundary: Nature, 389, 153-158.

Craig, H., 1957, Isotopic standards for carbon and oxygen and correction factors for mass spectrometric analysis of carbon dioxide: Geochimica et Cosmochimica Acta, 12, 133-149.

Croxen, F.W. III, Shaw, C.A., Sussman, D.R., 2007, Pleistocene Geology and Paleontology of the Colorado River Delta at Golfo de Santa Clara, Sonora, Mexico, in Reynolds, R.E. (ed.), Wild, Scenic and Rapid: a Trip Down the Colorado River Trough: The 2007 Desert Symposium Field Guide and Abstracts from Proceedings, California State University, Fullerton, Desert Studies Consortium, 84-89.

DeSantis, L.R.G., Feranec, R.S., MacFadden, B.J., 2009, Effects of global warming on ancient mammalian communities and their environments: PlosOne, 4(6), e5750.

Dompierre, H., 1995, Observations on the diets of six late Cenozoic North American camelids: Camelops, Hemiauchenia, Palaeolama, Procamelus, Alforjas, and Megatylopus: Toronto, University of Toronto, $\mathrm{PhD}$ dissertation, $478 \mathrm{p}$. 
Gervais, P., 1869, Zoologie et Paléontologie Générales. Nouvelles Recherches sur les Animaux Vertébrés Vivants et Fossiles. Première Série: Paris, France, Arthus Bertrand, Libraire-Éditeur, Libraire de la Société de Géographie, 263 p.

Graham, R.W., Lundelius, E.L. Jr., 2010, FAUNMAP II: New data for North America with a temporal extension for the Blancan, Irvingtonian and Early Rancholabrean. FAUNMAP II Database, version 1.0, available at $<$ http://www.ucmp.berkeley.edu/neomap/>, date accessed July 2014.

Gray, J.E., 1821, On the natural arrangement of vertebrose animals: London Medical Repository, 5, 296-310.

Honey, J.G., Harrison, A.J., Prothero, D.R., Stevens, M.S., 1998, Camelidae, in Janis, C.M., Scott, K.M., Jacobs, L.L. (eds.), Evolution of Tertiary Mammals of North America. Volume 1: Carnivores, ungulates and ungulate-like mammals: New York, Cambridge University Press, 439-462.

Koch, P.L., Zachos, J.C., Gingerich, P.D., 1992, Correlation between isotope records in marine and continental carbon reservoirs near the Paleocene/Eocene boundary: Nature, 358, 319-322.

Koch, P.L., Tuross, N., Fogel, M.L., 1997, The effects of sample treatment and diagenesis on the isotopic integrity of carbonate in biogenic hydroxylapatite: Journal of Archaeological Science, 24, 417-429.

Koch, P.L., Diffenbaugh, N.S., Hoppe, K.A., 2004, The effects of late Quaternary climate and $\mathrm{pCO}_{2}$ change on $\mathrm{C} 4$ plant abundance in the south-central United States: Palaeogeography Palaeoclimatology Palaeoecology, 207, 331-357.

Kohn, M.J., McKay, M.P., Knight, J.L., 2005, Dining in the Pleistocene - who's on the menu: Geology, 33, 649-652.

Kurtén, B., Anderson, E., 1980, The Pleistocene Mammals of North America: New York, United States, Columbia University Press, $442 \mathrm{p}$.

Lange, I.M., 2002, Ice Age mammals of North America: Missoula, Montana, Mountain Press Publishing Company, 226 p.

MacFadden, B.J., Cerling, T.E., 1996, Mammalian herbivore communities, ancient feeding ecology, and carbon isotopes: a 10 million years sequence from the Neogene of Florida: Journal of Vertebrate Paleontology, 16, 103-115.

Owen, R., 1848, Description of teeth and portions of jaws of two extinct anthracotherioid quadrupeds (Hyopotamys vectianus and Hyopotamys bovinus) discovered by the Marchioness of Hasting in the Eocene deposits on the N.W. coast of the Island of Wright: With an attempt to develop Cuvier's idea of the classification of pachyderms by the number of their toes: Quarterly Journal of the Geological Society of London, 4, 103-141.

PaleoDB (Paleobiology database), 2014, available at $<\mathrm{http}: / /$ paleodb. org/>, date accessed July 2014.
Pérez, E.A., 2013, Los mamíferos fósiles de la localidad de Puente de Piedra (Xenarthra, Glyptodontidae; Artiodactyla, Camelidae, Lamini) Grecia, Provincia de Alajuela, Costa Rica: Revista Geología América Central, 49, 33-44.

Prothero, D.R., Schoch, R.M., 2002, Horns, Tusks and Flippers. The Evolution of Hoofed Mammals: Baltimore and London, Johns Hopkins University Press, 311 p.

Quade, J., Cerling, T.E., Barry, J.C., Morgan, M.E., Pilbeam, D.R., Chivas, A.R., Lee-Thorp, J.A., van der Merwe, N.J., 1992, A 16 million year record of paleodiet using carbon and oxygen isotopes in fossil teeth from Pakistan: Chemical Geology, 94, 183-192.

Ruez, D.R., 2005, Earliest record of Palaeolama (Mammalia, Camelidae) with comments on "Palaeolama" guanajuatensis: Journal of Vertebrate Paleontology, 25(3), 741-744.

Sanders, A.E., 2002, Additions to the Pleistocene faunas of South Carolina, North Carolina, and Georgia: Transactions of the American Philosophical Society, New Series, 92(5), 1-152.

Semprebon, G.M., Rivals, F., 2010, Trends in the paleodietary habits of fossil camels from the Tertiary and Quaternary of North America: Palaeogeography Palaeoclimatology Palaeoecology, 295, 131-145.

Simpson, G.G., 1929, Pleistocene mammalian fauna of the Seminole Field, Pinellas County, Florida: Bulletin of the American Museum of Natural History, 56(2), 561-599.

Solounias, N., Tariq, M., Hou, S., Danowitz, M., Harrison, M., 2014, A new method of tooth mesowear and a test of it on domestic goats: Annales Zoologici Fennici, 51, 111-118.

Tovar, R.E., Sedov, S., Montellano-Ballesteros, M., Solleiro, E., Benammi, M., 2014, Paleosols, bones, phytoliths, and $\delta^{13} \mathrm{C}$ signatures of humus and teeth in the alluvial sequence of Axamilpa, Puebla: Inferences for landscape evolution and megafauna paleoecology during MIS 3-2 in southern Mexico: Catena, 112, 25-37.

Webb, S.D., 1965, The osteology of Camelops: Los Angeles County Museum Bulletin, 1, 1-54.

Webb, S.D., 1974, Pleistocene llamas of Florida, with a brief review of the Lamini, in Webb, S.D. (ed.), Pleistocene Mammals of Florida: Gainesville, Florida, The University Press of Florida, 170-213.

Wilson, D.E., Reeder, D.M. (eds.), 2005, Mammal Species of the World. A Taxonomic and Geographic Reference: Baltimore, Maryland, Johns Hopkins University Press, 2142 p.

Manuscript received: August 28, 2014

Corrected manuscript received: October 14, 2014

Manuscript accepted: October 20, 2014 